\title{
AOR
}

Selected Papers of \#AolR2020:

The $21^{\text {st }}$ Annual Conference of the Association of Internet Researchers

Virtual Event / 27-31 October 2020

\section{DIGITAL LABOR SOLIDARITIES, COLLECTIVE FORMATIONS, AND RELATIONAL INFRASTRUCTURES}

\author{
Cheryll Ruth R. Soriano, Ph.D \\ De La Salle University Manila \\ Rafael Grohmann, Ph.D \\ Unisinos University \\ Julie Yujie Chen, PhD \\ University of Toronto \\ Athina Karatzogianni, $\mathrm{PhD}$ \\ University of Leicester \\ Jason Vincent Cabañes, Ph.D \\ De La Salle University Manila \\ Paula Alves \\ Unisinos University \\ Adrija Dey, PhD \\ SOAS University of London
}

\section{Panel description}

Valorised under the guise of creativity and flexibility and also actively hailed by many governments as a solution to unemployment, there has been tremendous uptake on digital labor over recent years. And yet, research on digital worker experiences have shed light on the problematic realities of digital labor, which include increasing levels of stress and anxiety over financial and career instability, physical exhaustion, and isolation - all of which underscore the precarity that belie the optimistic facade of labor under the new economy (Hesmondhalgh and Baker, 2010, pp. 34-38; Graham, Hjorth \& Lehdonvirta, 2017; Lehdonvirta, 2016). These include instances of exploitation as well as Suggested Citation (APA): Soriano, C., Grohmann, R., Chen, J., Karatzogianni, A., Cabanes, J. Alves, P. (2020, October). Digital Labor Solidarities, Collective Formations, and Relational Infrastructures. Panel Presented at AolR 2020: The 21 ${ }^{\text {th }}$ Annual Conference of the Association of Internet Researchers. Virtual Event: AolR. Retrieved from http://spir.aoir.org. 
feelings of anxiety over job security and isolation due to having to work at intense speeds and with long, unsocial hours for fear of losing to competition (Beerepoot and Lambregts, 2014; Graham, et.al., 2017; Wood, Graham, Lehdonvirta, 2018; Wood, Lehdonvirta, Graham \& Anwar, 2019; van Doorn, 2017), as well as 'selfexploitation,' where workers are willing and prepared to take the risks of precarious work in hopes of obtaining future advancement (Hesmondhalgh \& Baker, 2011).

Expected to be working at home or mobile and physically disconnected, digital labor also raises important questions about how freelancer and entrepreneurial identities are perceived as barriers to effective collective organisation. Broadly, social capital theorists have argued that a sense of community of workers has declined with the fragmentation of work places and internationalisation of global value chains driven by technological development. This is accompanied by the decline in trust in large institutions, including labor unions, throughout the industrial world (Neilson \& Rossiter, 2008). Following the neoliberal ideology of entrepreneurialism that marked much of contemporary labor, digital workers are expected to overcome the challenges and channel entrepreneurial values to thrive in competitive labor markets by themselves. The notions of flexibility and entrepreneurialism that appear to be the key drivers for the popularity of digital labor pose unique challenges to collective organising, further compounded by the fact that when work is digital, workers are globally and regionally dispersed and also take on highly diverse jobs with diverse income ranges. These provide a limited basis for identity and social formation (Wood, Graham, \& Lehdonvirta, 2018; Lehdonvirta, 2016). Traditional avenues for addressing unequal employment relations are also perceived to be elusive as digital workers are also normally excluded from regulatory frameworks that enable collective representation.

That said, it has been contended that precarity has ironically spurred some workers to engage in 'deep attachment, affective bindings', and collaborative and communal practices (Arvidsson, Malossi, \& Naro, 2010). As such, possibilities for digital worker resistance, solidarity, and explorations of new models for unionising are being explored in a growing number of works (Wood, et.al, 2018, Wood, 2015; Irani and Silberman, 2013; Karatzogianni \& Matthews, 2020; Lehdonvirta, 2016). Some modest and alternative forms of collective organising have also been documented, with social media groups taking on a prominent role (Bryson, Gomez, \& Willman, 2010; Cant, 2019; Lehdonvirta, 2016; Wood, et.al., 2018; Heckscher \& McCarthy, 2014; Howcroft \& Bergvall-Kareborn, 2019; Geelan \& Hodder, 2017; Englert, Cant \& Woodcock, 2020, Soriano \& Cabañes, forthcoming). Yet it remains contentious whether this exponential increase in membership on social media platforms such as Facebook alongside possibilities for user-generated content can give rise to a new collaborative form of solidarity useful for productively "structuring of worker debates" (Bryson, Gomez, \& Willman, 2010, p.42).

Suggested Citation (APA): Soriano, C., Grohmann, R., Chen, J., Karatzogianni, A., Cabanes, J. Alves, P. (2020, October). Digital Labor Solidarities, Collective Formations, and Relational Infrastructures. Panel Presented at AoIR 2020: The 21 ${ }^{\text {th }}$ Annual Conference of the Association of Internet Researchers. Virtual Event: AoIR. Retrieved from http://spir.aoir.org. 
Looking at patterns of organisation and challenges to build solidarity across national and even regional experience will enrich the discussion in terms of the politics, nuances, and actual meaning of these spaces for local workers useful for examining worker expressions of resistance and solidarity amidst continuing technological development and platform reforms (Alacovska \& Gill, 2019; Grohman, forthcoming). A close examination of comparable and multiple forms of collective organisation, as well as the relational infrastructures underlying them, may demonstrate how workers challenge the dominant claims of global capitalism while steep in recognition of the opportunities that these offer.

Reflecting on experiences from China, Brazil, the Philippines, and India, this panel explores the following questions: What are the emerging collective formations among digital workers and what do they seek to achieve? What are the challenges in solidarity-building among digital workers and what conditions activate workers as political actors to organize as a collective force? What are the relational infrastructures and material dimensions of such forms of organisation? How do these formations seek to undo injustices while reflecting new power imbalances?

The first paper by Julie Chen examines the conditions that undermine collective action among ride-hailing drivers in China. Manifesting local asymmetries characterized by 'elite drivers' that contribute to narratives of success in this economy, the paper argues that these also work to hide and normalise the structural inequality existing prior to the rise of the platform economy and in turn works to undermine the potentials for drivers to build cross-group solidarity. The second paper by Cheryll Ruth Soriano and Jason Vincent Cabañes examines emerging forms of solidarity among digital platform workers in the Philippines, one of the largest platform labor supplying countries globally. The paper examines three emerging collective formations among local platform workers: the 'entrepreneurial solidarity' model in Facebook groups, the 'cooperative' model, and the 'alternative local labor platform' model. The paper teases out their characteristics as 'alternative cultures of organizing' in terms of how they identify' new subjects of labor,' 'new targets' to bargain with, new 'repertoires of struggle'; as well as the material dimensions of these organisational forms. The third paper by Rafael Grohmann and Paula Alves examines collective formations among platform drivers in Brazil. From the mapping of 18 unions and associations, the paper analyses how the different Brazilian organizations build meanings about the struggles of platform workers. Most associations do not understand the driver as a worker or "employee", and are supporters of a far-right President who does not like "unions". The paper finds that WhatsApp plays a central role in the communication and organisation of app-drivers and Facebook consolidates the meanings of unions and associations through the circulation of videos. The fourth paper by Athina Karatzogianni and Adrija Dey examines journalistic digital labor amidst the ideological (caste, religious, nationalist, or misogynist) polarisation

Suggested Citation (APA): Soriano, C., Grohmann, R., Chen, J., Karatzogianni, A., Cabanes, J. Alves, P. (2020, October). Digital Labor Solidarities, Collective Formations, and Relational Infrastructures. Panel Presented at AoIR 2020: The 21 ${ }^{\text {th }}$ Annual Conference of the Association of Internet Researchers. Virtual Event: AoIR. Retrieved from http://spir.aoir.org. 
during intense political events and trolling, the use of social media for crowdfunding, facilitating fact checking in grassroots activism and investigative journalism, as well as the way social media might be accelerating mobilisation and recruitment for political purposes. Vividly juxtaposing testimonies from key journalists (independent and mainstream), fact checkers, political activists and other political actors in India, it situates solidarity-building in journalistic digital labour in India in a context of hate speech, abuse or censorship and silencing. Exploring collective organisation as part of the digital worker's "work-world" -where power and control are continually exercised and asserted, reinforced and challenged, Jack Qiu (discussant) will respond and tease out key themes emerging from the panel.

\section{References}

Alacovska, A., \& Gill, R. (2019). De-westernizing creative labour studies: The informality of creative work from an ex-centric perspective. International Journal of Cultural Studies, 22(2), 195-212. https://doi.org/10.1177/1367877918821231

Arvidsson, A., Malossi, G. \& Naro, G. (2010) Passionate Work? Labour Conditions in the Milan Fashion Industry. Journal for Cultural Research, 14(3): 295-309, DOI: $\underline{10.1080 / 14797581003791503}$

Beerepoot, N., \& Lambregts, B. (2014). Competition in online job marketplaces: towards a global labor market for outsourcing services? Global Networks, 15(2), 1-20. https://doi.org/10.1111/glob.12051

Bryson, A., Gomez, R., \& Willman, P. (2010). Online social networking and trade union membership: What the Facebook phenomenon truly means for labor organizers. Labor History, $51(1)$, 41-53. https://doi.org/10.1080/00236561003654719

Cant, C. (2019). Riding for Deliveroo: Resistance in the New Economy. London: Polity.

Englert, S., Woodcock, J. \& Cant, C. (2020). Digital Workerism: Technology, Platforms, and the Circulation of Workers' Struggles. tripleC: Communication, Capitalism \& Critique, 18 (1), 132-145. https://doi.org/10.31269/triplec.v18i1.1133

Geelan, T., \& Hodder, A. (2017). Enhancing transnational labor solidarity: The unfulfilled promise of the Internet and social media. Industrial Relations Journal, 48(4): 345- 364. https://doi.org/10.1111/iri.12190

Gill, R., \& Pratt, A. (2008). In the social factory: Immaterial labour, precariousness and cultural work. Theory, Culture \& Society, 25(7-8), 1-30. doi:10.1177/0263276408097794

Suggested Citation (APA): Soriano, C., Grohmann, R., Chen, J., Karatzogianni, A., Cabanes, J. Alves, P. (2020, October). Digital Labor Solidarities, Collective Formations, and Relational Infrastructures. Panel Presented at AoIR 2020: The 21 ${ }^{\text {th }}$ Annual Conference of the Association of Internet Researchers. Virtual Event: AolR. Retrieved from http://spir.aoir.org. 
Graham, M. \& Anwar, A. A. (2019). The global gig economy: Towards a planetary labour market?. First Monday, 24(4). doi:10.5210/fm.v24i4.9913

Graham, M., Hjorth, I., \& Lehdonvirta, V. (2017). Digital labor and development: Impacts of global digital labor platforms and the gig economy on worker livelihoods. Transfer: European Review of Labor and Research, 23(2), 135-162.

Gregg, M. (2013). Presence bleed: Performing professionalism online. In M. Banks \& R. Gill (Eds.), Theorizing Cultural Work: Labor, Continuity and Change in the Cultural and Creative Industries (pp. 122-134). New York, NY: Routledge.

Grohmann, R. (2020). Plataformização do trabalho: entre dataficação, financeirização e racionalidade neoliberal. EPTIC journal, 22(1), 106-122.

Han, C. (2016). Precarity, precariousness, and vulnerability. Annual Review of Anthropology, 47(1).doi:10.1146/annurev-anthro-102116-041644

Heckscher, C., \& McCarthy, J. (2014). Transient solidarities: Commitment and collective action in post-industrial societies. British Journal of Industrial Relations, 52(4), 627-657.doi:10.1111/bjir.12084

Hesmondhalgh, D., \& Baker, S. (2010). A very complicated version of freedom: Conditions and experiences of creative labor in three cultural industries. Poetics, 38(1), 4-20. doi:10.1016/j.poetic.2009.10.001

Howcroft, D., \& Bergvall-Kåreborn, B. (2018). A typology of crowdwork platforms. Work, Employment and Society, 095001701876013.doi:10.1177/0950017018760136

Irani, L., \& Silberman, M.S. (2013). Turkopticon: Interrupting worker invisibility in Amazon Mechanical Turk, in Proceedings of the ACM Conference on Human Factors in Computing Systems (CHI), ACM, New York, NY.

Karatzogianni, A., \& Matthews, J. (2020). Platform Ideologies: Ideological Production in Digital Intermediation Platforms and Structural Effectivity in the "Sharing Economy." Television \& New Media, 21(1), 95-114. https://doi.org/10.1177/1527476418808029

Lehdonvirta, V. (2016). Algorithms that divide and unite: Delocalisation, identity and collective action in 'microwork. In J. Flecker (ed.) Space, Place and Global Digital Work: Dynamics of Virtual Work (pp. 53-80), London: Palgrave Macmillan.

Suggested Citation (APA): Soriano, C., Grohmann, R., Chen, J., Karatzogianni, A., Cabanes, J. Alves, P. (2020, October). Digital Labor Solidarities, Collective Formations, and Relational Infrastructures. Panel Presented at AoIR 2020: The 21 ${ }^{\text {th }}$ Annual Conference of the Association of Internet Researchers. Virtual Event: AolR. Retrieved from http://spir.aoir.org. 
Soriano, C.R. \& Cabañes, J.V. (2020). Entrepreneurial solidarities: Social media collectives and Filipino digital platform workers. Social Media + Society. https://doi.org/10.1177/2056305120926484

van Doorn, N. (2017). Platform labor: On the gendered and racialized exploitation of low- income service work in the 'on-demand' economy. Information, $\begin{array}{llll}\text { Communication \& Society, 20(6), 898-914. } & \text {. }\end{array}$ https://doi.org/10.1080/1369118X.2017.1294194

Wood, A., Lehdonvirta, V., \& Graham, M. (2018). Workers of the world unite? Online freelancer organisation among remote gig economy workers in six Asian and African countries. New Technology, Work and Employment, 33(2), 95-112. https://doi.org/10.1111/ntwe.12112

Wood, A. J. (2015). Networks of injustice and worker mobilisation at Walmart. Industrial Relations Journal, 46(4), 259-274. doi:10.1111/irj.12103

\title{
THE RELEVANCE OF LOCAL AND INTERGROUP RELATIONAL POLITICS FOR PLATFORM WORKERS
}

Julie Yujie Chen, PhD

University of Toronto

\begin{abstract}
The employment classification of platform workers has stirred global legislative, regulatory, and scholarly debates (Cherry, 2015; Prassl, 2018), as well as labor struggles and a new level of lobbying efforts from the tech industry. Look no further than the passage and the aftermath of California Assembly Bill 5. While the legal employment classification provides the "recognition" for the platform workers (Lee, 2019), the latters' lived experience of the transformation of digital work (Cherry, 2015), especially concerning the localized politics, is largely underexplored in the growing number of studies on gig workers, platform labor, and so on. Through examining the app-based drivers in China, the paper aims to shed new light on the roles played by the localized politics in shaping the lives of

Suggested Citation (APA): Soriano, C., Grohmann, R., Chen, J., Karatzogianni, A., Cabanes, J. Alves, P. (2020, October). Digital Labor Solidarities, Collective Formations, and Relational Infrastructures. Panel Presented at AoIR 2020: The 21 ${ }^{\text {th }}$ Annual Conference of the Association of Internet Researchers. Virtual Event: AoIR. Retrieved from http://spir.aoir.org.
\end{abstract}


different types of drivers (part-timers vs. full-timers, illegal vs. legal) and the potentials of the solidarity-building of drivers as a collective.

The term "new type of employment" is widely used in the government-issued documents and by academics in China to refer to the jobs that emerge on the digital platforms for on-demand services (e.g. for mobility or delivery) (Zhang, 2019). The term connotes the newness of the technology, of the organization of work, and of the "flexible" and entrepreneurial character of the platform work. Drivers on the ride-hailing apps are often championed as the emblem of the "quality jobs" among the new type of employment (Zhang, 2019). The paper juxtaposes the imagination of the "new type of employment" with the diverse practices used to manage a heterogeneous group of drivers at the local level, which corresponds with, complicates, and/or contradicts such an imagination. Materials used to analyze the discourse and imagination of the "new type of employment" come from the government-issued documents, scholarly literature, and the publications by the leading ride-hailing company. Materials used to examine drivers' experience and life come from my ethnographic work in two cities in China-namely, Beijing and Shenzhen.

The methodological orientation to study the discursive vector along with the real life politics of workers is informed by revelations on the importance of the discourses for the development and politics of the platform economy (Gillespie, 2010; Irani, 2015, 2019; Pasquale, 2016) and more generally, the science and technology studies (STS) approach toward studying the multiple political articulations of the technological system (Harding, 2009; Latour, 1988) against the context of global "platform capitalism" (Srnicek, 2016).

The paper first delineates how the regulations of ride-hailing service in China are embedded in the local politics, which for the least determine the legality of appbased drivers. Through comparing the policy differences in Beijing and Shenzhen, I will demonstrate that the varied criteria for an applicant to become a legal driver are motivated more by the longstanding local politics of population management and economic development than by the technological deterministic changes of the nature of work. The second part of the paper focuses on the lived experience and narratives of drivers in different employment types: legitimate subcontractor drivers and independent drivers with disputable legal status. Local politics propel drivers to construct their occupational identity around legitimacy and their perceived relations with other types of drivers. On one hand, legal private drivers distinguish themselves from other types of drivers and perform their legitimacy through professionalism and forming exclusive informal worker organizations to safeguard their legal rights. On the other hand, the localized legality poses a structurally insurmountable barrier for some non-local resident drivers (especially in Beijing) to achieve legitimacy and by extension, to resort to legitimate channels of work organization or labor protection. Their driving experience surrounds making ends meet or even thriving in the ride-hailing

Suggested Citation (APA): Soriano, C., Grohmann, R., Chen, J., Karatzogianni, A., Cabanes, J. Alves, P. (2020, October). Digital Labor Solidarities, Collective Formations, and Relational Infrastructures. Panel Presented at AoIR 2020: The 21 ${ }^{\text {th }}$ Annual Conference of the Association of Internet Researchers. Virtual Event: AolR. Retrieved from http://spir.aoir.org. 
service without being caught by the law enforcement. The alleged flexible schedule, the most prominent feature of the alleged "new form of employment", is compromised by the need to accommodate the local schedule of traffic control and temporality of the law enforcement. Driver's legitimacy thus turns into a source of "structured antagonism" (A. Wood \& Lehdonvirta, 2019) between different types of drivers.

Consequently, it is argued, that local and intergroup relational politics not only make legitimacy a site of contestations and performativity, but also dispel the myth-creation of the new type of employment and lay bare the workers' collective ambivalence toward the regulations (Dubal, 2019). The performativity of legitimacy and professionalism by the elite drivers contribute to the construction of the "successful stories" (Ravenelle, 2019) in the new type of employment. However, their performed elitism also hides and normalizes the structural inequality existing prior to the rise of the platform economy. Relational and at times antagonistic formation of occupational identity thus complicates the current understandings of labor relations on the digital platforms that are mediated and managed through algorithms (Rosenblat, 2018; Rosenblat \& Stark, 2016; A. J. Wood, Graham, Lehdonvirta, \& Hjorth, 2019), which may undermine the potentials for all drivers to build cross-group solidarity. Local politics and intergroup relations thus form two pillars which merit more scholarly and activist attention if a wide scope of app-based drivers' organizing were to be formed.

\section{References}

Cherry, M. A. (2015). Beyond Misclassification: The Digital Transformation of Work. Comparative Labor Law \& Policy Journal, 37, 577-602.

Dubal, V. B. (2019). An Uber Ambivalence: Employee Status, Worker Perspectives, \& Regulation in the Gig Economy (SSRN Scholarly Paper No. ID 3488009). Retrieved from Social Science Research Network website: https://papers.ssrn.com/abstract=3488009

Gillespie, T. (2010). The politics of 'platforms.' New Media \& Society, 12(3), 347364. doi: $10.1177 / 1461444809342738$

Harding, S. (2009). Postcolonial and feminist philosophies of science and technology: Convergences and dissonances. Postcolonial Studies, 12(4), 401421. doi: $10.1080 / 13688790903350658$

Irani, L. (2015). The cultural work of microwork. New Media \& Society, 17(5), 720-739. doi: 10.1177/1461444813511926

Irani, L. (2019). Chasing Innovation: Making Entrepreneurial Citizens in Modern India. Princeton, NJ: Princeton University Press.

Suggested Citation (APA): Soriano, C., Grohmann, R., Chen, J., Karatzogianni, A., Cabanes, J. Alves, P. (2020, October). Digital Labor Solidarities, Collective Formations, and Relational Infrastructures. Panel Presented at AoIR 2020: The 21 ${ }^{\text {th }}$ Annual Conference of the Association of Internet Researchers. Virtual Event: AolR. Retrieved from http://spir.aoir.org. 
Latour, B. (1988). Science in Action: How to Follow Scientists and Engineers through Society (REP edition). Cambridge, Mass: Harvard University Press.

Lee, C. K. (2019). The Social Question as the Struggle over Precarity The Case of China. In J. Breman, K. Harris, \& C. K. Lee (Eds.), The Social Question in the Twenty-First Century (pp. 58-76). Oakland, California: University of California Press.

Pasquale, F. (2016). Two Narratives of Platform Capitalism. Yale Law \& Policy Review, 35, 309-319.

Prassl, J. (2018). Humans as a Service: The Promise and Perils of Work in the Gig Economy. Oxford, New York: Oxford University Press.

Ravenelle, A. J. (2019). Hustle and Gig: Struggling and surviving in the sharing economy. Retrieved from https://www.ucpress.edu/book/9780520300569/hustleand-gig

Rosenblat, A. (2018). Uberland: How Algorithms Are Rewriting the Rules of Work (First edition). Oakland, California: University of California Press.

Rosenblat, A., \& Stark, L. (2016). Algorithmic Labor and Information Asymmetries: A Case Study of Uber's Drivers. International Journal of Communication, 10, 3758-3784.

Srnicek, N. (2016). Platform Capitalism. Hoboken, NJ: Wiley.

Wood, A. J., Graham, M., Lehdonvirta, V., \& Hjorth, I. (2019). Good Gig, Bad Gig: Autonomy and Algorithmic Control in the Global Gig Economy. Work, Employment and Society, 33(1), 56-75. doi: 10.1177/0950017018785616

Wood, A., \& Lehdonvirta, V. (2019). Platform Labour and Structured Antagonism: Understanding the Origins of Protest in the Gig Economy (SSRN Scholarly Paper No. ID 3357804). Retrieved from Social Science Research Network website: https://papers.ssrn.com/abstract=3357804

Zhang, C. (2019). Employment Revolution: Digital Business and the New Form of Employment in China. Beijing, China: China Workers Publishing House. [in Chinese]

Suggested Citation (APA): Soriano, C., Grohmann, R., Chen, J., Karatzogianni, A., Cabanes, J. Alves, P. (2020, October). Digital Labor Solidarities, Collective Formations, and Relational Infrastructures. Panel Presented at AoIR 2020: The 21 ${ }^{\text {th }}$ Annual Conference of the Association of Internet Researchers. Virtual Event: AolR. Retrieved from http://spir.aoir.org. 


\title{
DIGITAL PLATFORM LABOR IN THE PHILIPPINES: EMERGING FORMS OF COLLECTIVE ORGANISING
}

\author{
Cheryll Ruth R. Soriano, Ph.D \\ De La Salle University Manila \\ Jason Vincent Cabañes, Ph.D \\ De La Salle University Manila
}

\begin{abstract}
This paper builds on earlier works that have explored labor organising in the context of the global digital economy (Beck \& Brook, 2020; Bryson, Gomez, \& Willman, 2010; Chun \& Agarwala, 2016; Geelan \& Hodder, 2017; Heckscher \& McCarthy, 2014; Howcroft \& Bergvall-Kareborn, 2019; Irani \& Silbermann, 2013; Soriano \& Cabañes, 2020; Wood, et.al, 2018, Wood, 2015) and explores the characteristics and dynamics of emerging collective formations among Filipino digital platform workers. Here we focus on the case of the Philippines because it is one of the largest suppliers of digital labor globally. In the context of the increasing platformisation of labor at the heart of digital work--which the country's economic managers bet on as its "sunshine industries"--we look into how Filipino digital platform workers organise with shared agendas and perform 'acts of solidarity' (Beck \& Brook, 2020). We draw from a three-year digital ethnography project o to understand these how online workers deploy an assemblage of conditions that enable them to survive and organise within the constraints of the world's digital labor market.The fieldwork involved in-depth interviews with platform workers based in the cities of Manila, lligan, and Cebu, participant observation in Facebook groups for online freelancers, and attendance in related events.
\end{abstract}

The key contribution of our paper is that it underscores the nascent forms of collective organisation that is emerging even from within the strictures of contemporary platform labor. This is crucial because extant literature has Suggested Citation (APA): Soriano, C., Grohmann, R., Chen, J., Karatzogianni, A., Cabanes, J. Alves, P. (2020, October). Digital Labor Solidarities, Collective Formations, and Relational Infrastructures. Panel Presented at AolR 2020: The 21 ${ }^{\text {th }}$ Annual Conference of the Association of Internet Researchers. Virtual Event: AolR. Retrieved from http://spir.aoir.org. 
articulated many challenges for collective organisation among digital platform workers. Broadly, social capital theorists have argued that a sense of community of workers has declined with the fragmentation of work places and internationalisation of global value chains with the aid of technology (Wood, et.al, 2018). Mobility of labor and acute fluctuations in work location (i.e. work from home, digital nomads), coupled with high job and income diversity would appear to erode a sense of identity or belonging and poses difficulty for building the foundation for collective action. The transient nature of transactions for freelance and project-based digital workers can also be considered akin to a "spot auction market" (Howcroft \& Bergvall-Kareborn, 2019) which is based on individualised and small / immediate tasks that may make resistance with long-term perspectives seem untenable. Moreover, the usual absence of formal employeremployee relations can lead to "problems such as identifying exactly who the employer is and raises questions as to who is to be bargained with" (Howcroft \& Bergvall-Kareborn, 2019, p. 32). Given the ambiguous nature of the employeremployee relationship in platform work, workers have to diversify the target of their demands, and it is important for research to examine the shifts in targets for these demands, as well as the nature of these demands (Chun \& Agarwala, 2016).

This paper draws inspiration, however, from the scholarship that argues that amidst the precarity of digital labor, it can also enact "simultaneously, new forms of political struggle and solidarity that reach beyond the traditional models of the political party or trade union" (Gill \& Pratt, 2008, p. 3; Chun \& Agarwala, 2016; Beck \& Brook, 2020). To expand on these works, we inquire about what grounds there are for such solidarity to emerge and what forms these might take. We also take heed from how this scholarship raises concerns about how organising in the context of informality in the global South is strongly tied to local "institutions or systems of patronage" and emerging leaders and goals also come from the higher strata, thus reinforcing social asymmetries (Breman, 1977, pp.340-341). As such, in examining these new "cultures of solidarity" (Fantasia, 1988), we seek to examine the "cultivation of mutual affinities and associational bonds" beyond the workplace and in the spheres of workers' everyday lives (Beck \& Brook, 2020, p. 4). This examination of emerging innovations and experiments in organising would help broaden the labor movement agenda with "combining struggles for redistribution with struggles for recognition revealing the social worth of informality and precarity" while also challenging the notion that informal workers are "unorganizable" (Chun \& Agarwala, 2016, p. 635).

Many of the emerging works on digital labor and collective organisation have focused on exploring models for unionising, but we seek to broaden this discussion and consider other forms of emerging solidarities. Following Chun \& Agarwala's notion of "alternative cultures of organizing," this study seeks to signal key characteristics of organisation in the context of labor platformisation and informality, opening up opportunities for investigating new scales and spaces

Suggested Citation (APA): Soriano, C., Grohmann, R., Chen, J., Karatzogianni, A., Cabanes, J. Alves, P. (2020, October). Digital Labor Solidarities, Collective Formations, and Relational Infrastructures. Panel Presented at AoIR 2020: The 21 ${ }^{\text {th }}$ Annual Conference of the Association of Internet Researchers. Virtual Event: AolR. Retrieved from http://spir.aoir.org. 
beyond the formal workplace, and examining the involvement of neighborhoods, communities, and local institutions. The paper examines the nature and characteristics of three distinct forms of collective organisation emerging in the Philippine digital platform labor economy: 1) Facebook group model (i.e. social media 'communities' of online Filipino freelancers); 2) the freelancer cooperative model (through the case of Filipino Online Professionals Cooperative); and 3) the alternative local labor platform model (through the case of WrupUp). We tease out the dynamics of these organisational forms and how they differ in terms of: a) how they identify 'new subjects of labor', as well as the nature of aims and demands and ideological frames underlying their goals; b) 'new targets' or who or what is being challenged or bargained with; c) 'emerging repertoires of struggle' and how they interrupt, reinforce, and negotiate digital labor aspirational imaginaries; and d) 'material dimensions' of these organisational forms and the role of digital media in these collective formations. This analysis also seeks to understand the imaginaries tied to why digital workers choose to forge solidarities with others across each form of collective organisation, identifying alternative pathways for building solidarity among informal and precarious workers amidst the intersectionality of class and postcoloniality.

Finally, we examine the entanglement of local structural conditions as well as the dynamics of the platform labor economy that give rise to these forms of organising. We explore how local conditions, including State labor and ICT policies, as well as local social and economic structures of class and postcoloniality, are implicated in shaping the development of the platform economy, platform worker imaginaries, as well as the nature of these organisational forms. In turn, we will also describe how these solidarities may manifest power dynamics and asymmetries while also setting norms and standards in this largely unregulated sector.

\section{References}

Beck, V., \& Brook, P. (2020). Solidarities in and through work in an age of extremes. Work, Employment and Society, 34(1), 3-17. https://doi.org/10.1177/0950017019881566

Breman, J. (1977). Labour relations in the "formal" and "informal" sectors: Report of a case study in south Gujarat, India. Part 2. The Journal of Peasant Studies, 4(4), 337-359. doi:10.1080/03066157708438029

Bryson, A., Gomez, R., \& Willman, P. (2010). Online social networking and trade union membership: What the Facebook phenomenon truly means for labor organizers. Labor History, 51(1), 41-53.

Suggested Citation (APA): Soriano, C., Grohmann, R., Chen, J., Karatzogianni, A., Cabanes, J. Alves, P. (2020, October). Digital Labor Solidarities, Collective Formations, and Relational Infrastructures. Panel Presented at AoIR 2020: The 21 ${ }^{\text {th }}$ Annual Conference of the Association of Internet Researchers. Virtual Event: AolR. Retrieved from http://spir.aoir.org. 
Chun, J. J. \& Agarwala, R. (2016). "Global labour politics in informal and precarious jobs." In S. Edgell, H. Gottfried, \& E. Granter (eds.), Handbook of the Sociology of Work and Employment (pp. 634-650). Sage: London. pp. 634-650.

Fantasia, R (1988). Cultures of Solidarity: Consciousness, Action and Contemporary American Workers. Berkeley, CA: University of California Press. Geelan, T., \& Hodder, A. (2017). Enhancing transnational labor solidarity: The unfulfilled promise of the Internet and social media. Industrial Relations Journal, 48(4): 345- 364.

Gill, R., \& Pratt, A. (2008). In the social factory: Immaterial labour, precariousness and cultural work. Theory, Culture \& Society, 25(7-8), 1-30. doi:10.1177/0263276408097794

Heckscher, C., \& McCarthy, J. (2014). Transient solidarities: Commitment and collective action in post-industrial societies. British Journal of Industrial Relations, 52(4), 627-657.doi:10.1111/bjir.12084

Irani, L., \& Silberman, M.S. (2013). Turkopticon: Interrupting worker invisibility in Amazon Mechanical Turk, in Proceedings of the ACM Conference on Human Factors in Computing Systems (CHI), ACM, New York, NY.

Lehdonvirta, V. (2016). Algorithms that divide and unite: Delocalisation, identity and collective action in 'microwork. In J. Flecker (ed.) Space, Place and Global Digital Work: Dynamics of Virtual Work (pp. 53-80), London: Palgrave Macmillan.

Soriano, C. \& Cabañes, JV. (2020). Entrepreneurial solidarities: Social media collectives and Filipino digital platform workers. Social Media + Society. https://doi.org/10.1177/2056305120926484

Wood, A., Lehdonvirta, V., \& Graham, M. (2018). Workers of the world unite? Online freelancer organisation among remote gig economy workers in six Asian and African countries. New Technology, Work and Employment, 33(2), 95-112.

Suggested Citation (APA): Soriano, C., Grohmann, R., Chen, J., Karatzogianni, A., Cabanes, J. Alves, P. (2020, October). Digital Labor Solidarities, Collective Formations, and Relational Infrastructures. Panel Presented at AoIR 2020: The 21 ${ }^{\text {th }}$ Annual Conference of the Association of Internet Researchers. Virtual Event: AolR. Retrieved from http://spir.aoir.org. 


\title{
UNIONS AND ASSOCIATIONS OF APP-DRIVERS IN BRAZIL: THE MEANINGS IN CIRCULATION OF PLATFORM WORKERS' STRUGGLES
}

\author{
Rafael Grohmann, Ph.D \\ Unisinos University \\ Paula Alves \\ Unisinos University
}

\begin{abstract}
In the current scenario of digital labor, there are emergencies of unions and collective organizations of platform workers around the world. However, these collective formations are not the same everywhere, in the same way that digital labor itself has a geopolitical dimension (Graham \& Anwar 2019). Neilson (2018), Cohen and De Peuter (2018), Woodcock (2020) and Englert, Woodcock and Cant (2020) wrote about workers' organization in the areas of technology, journalism, games and app-drivers in a Global North context. However, digital labor in the Global South is marked by different imaginaries and practices, involving issues of class and coloniality (Soriano \& Cabañes, 2020). In Brazil, for example, the 'gig' is historically the norm, and not the exception, in the labor market (Grohmann 2020). Thus, the platformization of labor (Casilli \& Posada $2019)$ ratifies the condition of most Brazilian workers. According to Abílio (2020), there is a productive and monopolized appropriation of the living in the global peripheries by digital platforms.

This paper aims to map formal collective organizations of platform workers in Brazil, such as unions and associations, specifically platform drivers. Authors like

Suggested Citation (APA): Soriano, C., Grohmann, R., Chen, J., Karatzogianni, A., Cabanes, J. Alves, P. (2020, October). Digital Labor Solidarities, Collective Formations, and Relational Infrastructures. Panel Presented at AoIR 2020: The 21 ${ }^{\text {th }}$ Annual Conference of the Association of Internet Researchers. Virtual Event: AolR. Retrieved from http://spir.aoir.org.
\end{abstract}


Woodcock and Graham (2019) and Cant (2019) have underlined the role of digital communication in the organization of platform workers, such as groups on WhatsApp and Facebook. There is also a dependency on Big Tech digital infrastructures and their affordances. In addition, there is the institutionalization of workers' organization through unions and associations. The research wants to know how the different Brazilian organizations build meanings about the struggles of platform workers. In South America, the first association was Associación de Personal de Plataformas (APP), in Argentina. In January 2020, there was the first international meeting of app-drivers' organizations, with the participation of 23 countries and the support from the Open Society. The South American participants were Argentina, Brazil, Chile, Uruguay, Panama and Costa Rica. Then, the International Alliance of App-Based Transport Workers (IAATW) was created. This shows, as stated by Woodcock (2020) and Chun \& Agarwala (2016), that platform workers are not "unorganizable."

In Brazil, there are 17 app-drivers' associations and unions from 12 different cities. Most were founded in 2018. The highlights are Sindmaap, from Brasilia - a union with 30 thousand workers and affiliated to the largest central of workers in Brazil, CUT - and Ampa, from Rio de Janeiro, an association whose leader has helped to create other associations (such as the city of Juiz de Fora, Minas Gerais) and led the creation of the league of app drivers associations in Brazil, which aims to be nationally recognized as the main organization in the country. The research methodology involves analysis of the organizations' websites and interviews with leaders of associations and unions, emphasizing discursive aspects (Codagnone, Karatzogianni \& Matthews, 2018). The analysis presents the following dimensions: a) ideologies and worldviews of organizations about (digital) labor, including the main demands of workers; b) the role of digital platforms in the institutionalization of the organization of app-drivers and the material dimension of the organizational form.

The results reveal differences between the associations and unions of appdrivers in Brazil. While unions, in a minority, are linked to the left-wing and to others workers' movements in the country, the associations - mostly in the Brazilian app-drivers context - want to distance themselves from unions, in the discursive and material aspects, and consider themselves "entrepreneurs" on digital platforms . In addition to this entrepreneurial rationality, in the terms of Dardot \& Laval (2014), there is the support of drivers for Brazilian President Jair Bolsonaro and his far-right agenda, which shows the complex relationships between local politics and global digital platforms. In general lines, these associations do not want to be recognized as "employed" by platforms like Uber, unlike the context of the United States, for example (Rosenblat, 2018). Their claims are for higher rates and even a percentage of the data labor generated by drivers. There are statements from the leaders saying that they are not aligned with labor and workers' movements. They also struggle for the safety of drivers, in the context of violence and murders of these platform workers.

Suggested Citation (APA): Soriano, C., Grohmann, R., Chen, J., Karatzogianni, A., Cabanes, J. Alves, P. (2020, October). Digital Labor Solidarities, Collective Formations, and Relational Infrastructures. Panel Presented at AoIR 2020: The 21 ${ }^{\text {th }}$ Annual Conference of the Association of Internet Researchers. Virtual Event: AolR. Retrieved from http://spir.aoir.org. 
Regarding digital infrastructures, WhatsApp is the main platform for communication between workers, corroborating other research such as Cant (2019). In a Brazilian context, WhatsApp is also the central space for the political communication of Jair Bolsonaro's supporters (Evangelista \& Bruno 2019). Facebook pages are a hub for circulation of content about these organizations. The videos recorded by the leaders of associations and unions and circulated by WhatsApp and Facebook play a central role in the sedimentation of their proposals and worldviews, which can be exemplified by the comments of others drivers on social media reinforcing support for the leaders of the organizations. The analysis reveals struggles over meanings between the different associations and unions regarding the circulation of workers' struggles (Englert, Woodcock \& Cant 2020), including the discursive aspect. These differences, and even contradictions, between unions and associations of app-drivers in Brazil reinforce, as Cant (2019) states, that digital platforms are a laboratory of class struggles.

\section{References}

Abilio, L. (2020). Plataformas digitais e uberização: a globalização de um Sul administrado? Contracampo: Brazilian Journal of Communication, 39 (1).

Cant, C. (2019). Riding for Deliveroo: Resistance in the new economy. London: Polity.

Casilli, A. \& Posada, D. (2019). The Platformization of Labor and Society. In M. Graham \& W. Dutton (ed.s). Society and the Internet (p. 293-306). Oxford: OUP.

Chun, J. J. \& Agarwala, R. (2016). "Global labour politics in informal and precarious jobs." In S. Edgell, H. Gottfried, \& E. Granter (eds.), Handbook of the Sociology of Work and Employment (pp. 634-650). Sage: London. pp. 634-650.

Codagnone, C.; Karatzogianni, A. \& Matthews, J. (2018). Platform Economics: Rhetoric and Reality in the "Sharing Economy". London: Emerald.

Cohen, N. \& De Peuter, G. (2018). "I work at Vice Canada and I need a union": organizing digital media. In Labour Under Attack: Anti-unionism in Canada (pp. 114-128). Nova Escócia: Fernwood.

Dardot, P. \& Laval, C. (2014). The New Way of World: On Neoliberal Society. London: Verso.

Englert, S.; Woodcock, J. \& Cant, C. (2020). Digital workerism: technology, platforms and the circulation of workers' struggles. tripleC: Communication, Capitalism \& Critique, 18 (1).

Suggested Citation (APA): Soriano, C., Grohmann, R., Chen, J., Karatzogianni, A., Cabanes, J. Alves, P. (2020, October). Digital Labor Solidarities, Collective Formations, and Relational Infrastructures. Panel Presented at AolR 2020: The $21^{\text {th }}$ Annual Conference of the Association of Internet Researchers. Virtual Event: AolR. Retrieved from http://spir.aoir.org. 
Evangelista, R.; Bruno, F. (2019). WhatsApp and political instability in Brazil: targeted messages and political radicalisation, Internet Policy Review, 8 (4), 123.

Graham, M. \& Anwar, M. (2019). The Global Gig Economy: towards a planetary labour market? First Monday, 24 (4).

Grohmann, R. (2020). Plataformização do trabalho: entre dataficação, financeirização e racionalidade neoliberal. EPTIC journal, 22(1), 106-122.

Neilson, T. (2018). Unions in Digital Labour Studies: a review of information society and Marxist autonomist approaches. tripleC: Communication, Capitalism \& Critique, 16 (2).

Rosenblat, A. (2018). Uberland: How Algorithms Are Rewriting the Rules of Work. Berkeley: University of California Press.

Soriano, C. \& Cabañes, J.V. (2020). Between 'world class work' and 'proletarianised labor': Digital labor imaginaries in the Global South. In Routledge Companion to Media and Class. New York: Routledge.

Woodcock, J. (2020). How to beat the boss: Game Workers Unite in Britain. Capital \& Class. Online First.

Woodcock, J. \& Graham, M. (2019). The Gig Economy: A Critical Introduction. London: Polity.

Suggested Citation (APA): Soriano, C., Grohmann, R., Chen, J., Karatzogianni, A., Cabanes, J. Alves, P. (2020, October). Digital Labor Solidarities, Collective Formations, and Relational Infrastructures. Panel Presented at AoIR 2020: The 21 ${ }^{\text {th }}$ Annual Conference of the Association of Internet Researchers. Virtual Event: AolR. Retrieved from http://spir.aoir.org. 


\title{
THE DARK SIDE OF JOURNALISTS' DIGITAL LABOUR WITHIN INDIAN POLITICAL CULTURE
}

\author{
Athina Karatzogianni, $\mathrm{PhD}$ \\ University of Leicester \\ Adrija Dey, PhD \\ SOAS University of London
}

\begin{abstract}
This presentation stems from a research project investigating how politics is mediated by and through social media during elections and/or significant political events in India. The project focuses on the use of WhatsApp, Twitter and Facebook by governmental (politicians), corporate (political marketing, PR and campaign managers, and digital campaign workers) and civil society actors (political activists, investigative journalists, social movement and NGO advocacy actors). The project analyses in what ways the use of social media is shaping Indian political culture and political ideology, enquiring into filter bubbles, polarisation, fake news, disinformation architectures, hate speech, the rise of far-right populism, leaks and scandals, such as Cambridge Analytica, and other contemporary digital phenomena. It is set to compare India to similar research during other elections (US, Brazil, Philippines) and investigates what are the differences (cultural/religious/socioeconomic/political) and/or similarities (digital political economy and structural conditions) in relation to social media campaigns particularly during elections.

Suggested Citation (APA): Soriano, C., Grohmann, R., Chen, J., Karatzogianni, A., Cabanes, J. Alves, P. (2020, October). Digital Labor Solidarities, Collective Formations, and Relational Infrastructures. Panel Presented at AoIR 2020: The 21 ${ }^{\text {th }}$ Annual Conference of the Association of Internet Researchers. Virtual Event: AolR. Retrieved from http://spir.aoir.org.
\end{abstract}


The research poses the following questions: 1 . Why and how Indian political actors used and experienced social media, such as WhatsApp, Twitter and Facebook use for political purposes, particularly before and during the 2019 Elections; 2. What are the key topics, discourses and ideological productions in social media political culture in India; 3 . What are key issues journalists and other users face when they engage in politics through social media in India. The methodology for this study includes interviews and participant observation of online discussions and during physical political events. During netnography relevant actors were identified for interview in the field in Delhi.

Here for the purpose of this panel, we shall present a particular strand concerning how journalistic digital labour plays out in such a context of hate speech, abuse or censorship and silencing they might face. Further, we enquire into ideological (caste, religious, nationalist or misogynist) polarization during intense political events and trolling, the use of social media for crowdfunding, facilitating fact checking in grassroots activism and investigative journalism, as well as the way social media might be accelerating mobilization and recruitment for political purposes.

In a report published in 2018 by Reporters Without Borders (RSF), they voiced their concern about the scale of a new threat to press freedom and the mass harassment of journalists online. Their analysis showed that the online attack on journalists took place in 3 stages- Disinformation (drowning out journalistic content with flood of fake news and pro-government content); Amplification (progovernment content is artificially enhanced by commentators who are paid by the government to post messages on social networks or by bots, computer programmes that automatically generate posts); Intimidation (journalists are personally targeted, insulted and threatened, in order to discredit them and reduce them to silence (Reporters Without Borders, 25 July 2018). In context of India the report states, 'a, trolls who have been dubbed "yoddhas" by Prime Minister Narendra Modi, threaten and insult journalists and flaunt their hostility towards women, minorities, and untouchables. Calling themselves "Proud Hindu," "Bharat mata Ki Jai" ("Long Live our Mother India") or "Desh Bhakt" (Patriot"), they post pictures of Hindu divinities or Modi in their profile photos on social networks' (Reporters Without Borders, 2018, p.6). In April 2015, India's minister of state for external affairs, General V. K. Singh used the term 'presstitutes' (A play on the word prostitutes) to describe journalists criticizing him for an earlier comment. Since then, the term has been extensively used to troll and harass especially female journalists (Dias, 9 May 2016).

An issue that is particularly interesting is the threat of direct physical violence stemming from what one states online, which has resulted in an intense culture of fear. In their interviews participants narrated instances of them being followed, stalked, threatened and blackmailed. One of the participants who is in an editorial

Suggested Citation (APA): Soriano, C., Grohmann, R., Chen, J., Karatzogianni, A., Cabanes, J. Alves, P. (2020, October). Digital Labor Solidarities, Collective Formations, and Relational Infrastructures. Panel Presented at AoIR 2020: The 21 ${ }^{\text {th }}$ Annual Conference of the Association of Internet Researchers. Virtual Event: AolR. Retrieved from http://spir.aoir.org. 
position in a leading newspaper in India stated that hate speech and trolling have become an everyday affair and it's not only limited to online but also phone calls and people turning up at the newspaper office. 'Newspaper offices have armed guards now. It has happened in the past 5 years..... There is a culture of fear. We don't know when it converts from the online to the offline... We are much more cautious about what we do now' (Participant 4, 5 April 2019, interview with authors, New Delhi). Another male journalist called trolling in India a 'work-hazard'. He spoke about an incident of prolonged trolling which led to death threats against him, rape threats against his wife and his home address being openly circulated on Twitter. He stated, 'I was super vocal about political opinions but I stopped after this. I now stick to fun tweets' (Participant 3, 5 April 2019, interview with authors, New Delhi). Another participant on speaking about this stated, 'there is a culture of fear. No one wants to question Modi' (Participant 5, 6 April 2019, interview with authors, New Delhi).

Every woman interviewed for the research spoke about the sexual nature of the trolling including threats of rape, morphed images being circulated online and phone numbers being leaked. Rana Ayyub, a prominent female journalist talking about her experience stated, 'The lowest that the trolls went was when they morphed my face on a pornographic video and sent it to my relatives, my parents and my neighbours. It was unbelievable' (Khybri, 28 August 2018). Gudipaty's (2017, p.302) research on trolling of female journalists reveal that if they write 'soft stories' on fashion or entertainment they are not trolled but if they write something on politics of religion or if their work is considered feminist in any way, getting trolled was to be expected. Hence, following the BJP government's nationalist agenda, trolling has become yet another way of propagating hyper nationalism, enforcing strict gender roles, rewriting concepts of citizenship and silencing and discipling dissenting voices.

However, it was not only women but also men in India who echoed the same views. Many of the men we interviewed, especially journalists and social activists, complained about the incessant and dark nature of the trolling leading to either them leaving social media completely or censoring what they say and how they say it to a very large extent (Participant 1, 4 April 2019, interview with authors, New Delhi; Participant 3, 5 April 2019, interview with authors, New Delhi; Participant 4, 5 April 2019, interview with authors, New Delhi).

This study vividly and rigorously juxtaposes testimonies from key journalists (independent and mainstream), fact checkers, political activists and other political actors in India and their experience of the effect of social media use for political purposes. It provides elements for comparison to studies in other countries for this panel with colleagues researching on the Philippines and Brazil.

\section{References}

Suggested Citation (APA): Soriano, C., Grohmann, R., Chen, J., Karatzogianni, A., Cabanes, J. Alves, P. (2020, October). Digital Labor Solidarities, Collective Formations, and Relational Infrastructures. Panel Presented at AoIR 2020: The 21 ${ }^{\text {th }}$ Annual Conference of the Association of Internet Researchers. Virtual Event: AolR. Retrieved from http://spir.aoir.org. 
Dias, C. D. (2016). Female Journalists, Called "Presstitutes", Face Extreme Harassment in India. Retrieved September 9, 2019, from https://www.vice.com/en_us/article/53n78d/female-journalists-called-presstitutesface-extreme-harassment-in-india

Gudipaty, N. (2017). Gendered Public Spaces. Online trolling of women journalists in India. Comunicazione Politica, (2), 299-310.

Khybri, G. (2018). How Threats on Twitter Manifest In Real Life: Indian Troll Tales. Retrieved September 9, 2019, from https://xiaomi.dailyhunt.in/news/india/english/the+quint-epaperquint/how+threats+on+twitter+manifest+in+real+life+indian+troll+tales-newsid95544999?ps=N\&pn=0\&mode=wap\&\&nsk=women-updates-women

Reporters Without Borders. (2018). Online harassment of journalists: the trolls attack. Retrieved from https://rsf.org/en/news/rsf-publishes-report-onlineharassment-journalists

Suggested Citation (APA): Soriano, C., Grohmann, R., Chen, J., Karatzogianni, A., Cabanes, J. Alves, P. (2020, October). Digital Labor Solidarities, Collective Formations, and Relational Infrastructures. Panel Presented at AoIR 2020: The 21 ${ }^{\text {th }}$ Annual Conference of the Association of Internet Researchers. Virtual Event: AolR. Retrieved from http://spir.aoir.org. 